South Asia Multidisciplinary Academic Journal

$24 / 25 \mid 2020$

The Hindutva Turn: Authoritarianism and Resistance in India

\title{
Yogi Adityanath's Background and Rise to Power
}

Véronique Bouillier

\section{OpenEdition}

Journals

Electronic version

URL: http://journals.openedition.org/samaj/6778

DOI: $10.4000 /$ samaj.6778

ISSN: $1960-6060$

Publisher

Association pour la recherche sur l'Asie du Sud (ARAS)

\section{Electronic reference}

Véronique Bouillier, "Yogi Adityanath's Background and Rise to Power », South Asia Multidisciplinary Academic Journal [Online], 24/25 | 2020, Online since 09 November 2020, connection on 15 December 2020. URL : http://journals.openedition.org/samaj/6778 ; DOI : https://doi.org/10.4000/samaj.6778

This text was automatically generated on 15 December 2020.

\section{(2) $(\mathcal{Q} \Theta \Theta$}

This work is licensed under a Creative Commons Attribution-NonCommercial-NoDerivatives 4.0

International License. 


\title{
Yogi Adityanath's Background and Rise to Power
}

\author{
Véronique Bouillier
}

1 Styled "the Hindu Priest" or "the Hindu Monk," even "the Fanatic Hindu Monk" by the Press, Adityanath, the Chief Minister of Uttar Pradesh, is a Yogi, specifically a member of the Shaiva sect of the Nath Yogis. ${ }^{1}$ The Nath Yogis are characterized by the huge earrings that they wear in the thick of the ear, the cartilage being split in the middle, hence their popular name of Kanphata Yogis or Yogis with split ears. But Adityanath's golden rings are very discrete.

Being mahant, i.e. chief of the monastery (math) of Gorakhpur, Adityanath is both the heir to an ancient ascetic tradition dating at least from late sixteenth century, and the present successor of a movement of secularization which started in the 1930s with the powerful and political mahant Digvijaynath (b.1894, mahant 1935-d.1969). This movement constitutes a break with the former Nath Yogi attitude towards worldly power. The Yogis were traditionally well known for their supposedly superhuman powers, their siddhis, which they obtained through Hatha Yoga, rituals, or alchemical practices. However, they often used their reputation as wonder-workers in rather mundane ways, to help would-be kings to assert their domination or maintain their temporal supremacy. In exchange they were granted huge worldly possessions-lands, villages, means to sustain their affluent monasteries. They were kings' counsellors, spiritual as well as temporal advisers. ${ }^{2}$ But the $20^{\text {th }}$ century ushered in a new configuration in which religious figures entered the political arena. The Gorakhpur heads, from Digvijaynath onwards, understood that to maintain their former level of influence, they had to get involved in the new paradigm of modernity-i.e. development-, as embodied by educational and medical institutions. That was an initial move that Gorakhpur math later shared with other Nath Yogi institutions such as the Asthal Bohar monastery (Haryana). But that was not sufficient to implement the ideas dear to Digvijaynath: to make India-Bharat-a Hindu Nation. Already involved in politics even before his nomination as mahant, he managed to turn his status and function into a powerful tool to propagate his vision of India and insert himself directly 
into the heart of political action, through electoral game. His two successors took the same line, but Adityanath went even further in this interweaving of politics and religion, maintaining his high status as religious authority and competing in the political field of the Hindu right, to the point of becoming Chief Minister and a key element of Narendra Modi's strategy.

My purpose here is to question his career as Hindutva flagbearer in the context of his Nath Yogi identity.

The Nath Yogis, as kings' counsellors and wonder-workers, were in competition with their Muslim counterparts, the Sufi religious experts of the Muslim sultans and Moghul princes. And their rivalry was fed by an undeniable closeness.

5 This proximity ${ }^{3}$ was conspicuous in various fields: philosophical quest, shared legendary world, literature, science, history.

6 The Nath Yogis of today claim Gorakhnath as their founder. This saint about whom we have no historical data, probably lived in the $12^{\text {th }}$ century and is credited with Sanskrit treatises on Hatha Yoga, the yoga, which the modern Yoga that has become so popular all over the world partly originates from, and that the Nath Yogis now claim as their tradition. The sect was organized later on, late $16^{\text {th }}$ century probably, divided into various branches-panth-hence the canonical appellation of the sect as Barahpanthistwelve branches-and it had a huge influence in various domains. The yogic philosophy, the vision of the body as a microcosm of the macrocosm, the practices of breath control were widely shared with the Sufis who "commented with interest on particular yogic techniques and concepts" (Ernst 2016:280). ${ }^{4}$ Texts and teachings were exchanged in places where both kinds of mystics were welcomed, the Sufi dargahs or tombs of saints, and the Nath ashrams or maths, monasteries. Indian Sufi romances, the Indo-Sufi masnavis (such as Candayan and Madhumalati) combine metaphysical quest of the soul in the love of God with a Nath vocabulary. Scientific exchanges also took place: Muslim physicians looking for data on the production of mercurial and metallic drugs (cf. Speziale forthcoming) for alchemical purposes. Spiritual and scientific exchanges did not prevent rivalry nor competition and many stories tell of public demonstrations of miracles or wonders intended to prove the superiority of the Sufi or Nath ascetic (cf. Digby 1970). Many narratives however testify to fluid identities, devotees attracted to holy men whatever their religious label and holy men denying any sectarian belonging. The Gorakh-bani, a collection of vernacular aphorisms attributed to Gorakhnath, contains several verses acknowledging the true devotion of the Nath Yogi, as distinct from both religions: i.e. sabdi 68: "The Hindu meditates in the temple, the Muslim in the Mosque // The Yogì meditates on the supreme goal, where there is neither temple nor mosque." A specificity that emperor Akbar recognized in permitting a special place to be built for feeding the poor Yogis, alongside the two spaces devoted to poor Muslims and poor Hindus (anecdote told by Badā'ūnī, see Pinch 2006:51).

7 Thus, fluid boundaries and mutual esteem have been characteristics of the relationships between the Nath Yogis and the Muslims since pre-modern times. The legends surrounding the foundation of Gorakhpur monastery, the hometown of Yogi Adityanath, convey the same message. 


\section{Gorakhpur}

8 Local stories relate the name Gorakhpur to the siddha Gorakhnath and his choosing to make his abode there after a contest with the Jwalamuki goddess (Bouillier 2017:275). His forested hermitage was well-respected by the local people. However, stories are told about Alaud-Din Khilji (1296-1316) and Aurangzeb (1659-1707) destroying a Gorakhnath temple, but there is no historical evidence nor probability. ${ }^{5}$ History and legend combined later on to account for the establishment of the two main religious centers of the place. It is told that one day Asaf-ud-Daulah (1775-1797), the Awadh nawab, went hunting in the jungle and ran across the place where a holy man, Baba Roshan Ali Shah, was meditating naked, close to a fire. Astonished by his ascetic feats, the nawab wanted to give him land and riches but the Baba refused and told him instead to go visit his friend Gorakhnath who was meditating nearby. The Nawab duly impressed by the two men gave them each half of the Gorakhpur territory. The northern part went to Gorakhnath to build a monastery and the southern one to Roshan Ali for an imambara, ${ }^{6}$ where he was later buried. ${ }^{7}$ The imambara expanded his territory with Roshan Ali's successor, his nephew, called the Miyan Sahib and the area was known as Miyan Bazar (until Adityanath renamed it Maya Bazar). Thus, the Nath monastery and the imambara remained the two religious places of importance and their relationships were known to be friendly up until recently.

9 Both places are situated in Muslim areas. The Gorakhpur math is surrounded by weavers, whose workshops are on lands traditionally given by the math. ${ }^{8}$ The Muslim weavers used to consider the temple as theirs and came numerous to its main festival, the Magh Sankranti mela. During this month-long festival, many of the temporary shops are held by Muslims, and, in Gorakhpur, the Muslims were even considered as the vote bank of the math. ${ }^{9}$

10 The Gorakhnath temple was also dear to the particular community of the Muslim Yogis whose existence is attested throughout Northern India. Well represented in the villages of Eastern Uttar Pradesh, they are Muslim singers and musicians and often go wandering from place to place according to religious calendars, both Hindu and Muslim. They sing or used to sing Hindu songs or epics and most specifically the Nath epics of Gopicand and Bhratrihari. But the few Indian journalists ${ }^{10}$ and handful of researchers who have attended to this tradition insist on their current reluctance and even fear to continue to acknowledge their heritage. As one interviewee said to $\mathrm{S}$. Chaturvedi (2016):

We definitely want to sing. Despite the fact that we are Muslims, we have both Kuran and Ramayan in our home. We consult Ramayan to draw stories for singing. We are disciple of Guru Gorakhnath and his disciple Gopichand and Bharthari. Earlier no one was bothered to ask us that whether we are Hindu or Muslim. Now even housewives ask us such questions. Everywhere there is Hindu Muslim issue. This is development of last four-five decades or so. I have a fear factor that, what if someone will ask that why I am singing praises of Guru Gorakhnath and talking about Ram. This fear is from both sides. (P. 164)

Both Hindu and Muslim fundamentalists are now against their own former tradition of encompassing devotion. 


\section{The politicization of the monastery}

11 The active involvement of the Gorakhpur monastery in the political game started in the second decade of the $20^{\text {th }}$ century. Before that it seems that the math was relatively important but that its mahants, its heads, were more involved in spiritual matters, and left the worldly alone. Everything changed with the mahant Digvijaynath (b.1894enthronement 1935-d.1969). Born to the princely family of Mewar as Rana Nanhu Singh, then orphaned, he was committed by an uncle to the care of the Gorakhpur monastery where he spent his youth, studying in a technical college. His real interest was politics and in 1921 he joined the Congress Party but resented its policy of appeasement towards the Muslims. He changed affiliation for the Hindu Mahasabha ${ }^{11}$ after having heard Savarkar speak. The involvement with the Nath sampradaya was not his priority and he was initiated quite late, at 41 , in 1933, in order to take the mahantship of the math which was at this time involved in intricate succession conflicts. 12

As A.K. Banerjea (1979), the main philosopher and historian of the math, wrote:

When the present Mahant [Digvijaynath] succeeded to the guddee (i.e. gaddi, the throne, the seat of mahant), he found the institution economically in a poor condition...the previous Mahants, who were as a rule other-worldly saintly persons, were naturally indifferent to such outer improvements of the institution. (P. 16)

13 In the beginning of the $20^{\text {th }}$ century, the prominent figure of the monastery was Gambhirnath, "a great Mahayogi who was universally recognized as a perfectly enlightened saint with superhuman Yogi powers and who would almost always remain in a deeply meditative mood with the least part of his consciousness concerned with the external affairs" (Banerjea 1979:16-17). Gambhirnath was even credited with the miraculous cure of the child Digvijaynath whom he revived by putting him under his bed (Mahant Digvijaynath smrti-granth 1971:164). Gambhirnath was not the official mahant but was in charge of the math because of the incompetency of the incumbent Sundarnath, or because of internecine feuds. But Gambhirnath died in 1917 and the followings years saw his disciples fighting for the mahant's position in the Courts. After the death of Sundarnath, the fight went on until the death in 1932 of his disciple Gokulnath, which lead the High Court to finally nominate Brahmanath for the position of mahant in 1932. Brahmanath was Gambhinath's disciple, and the guru of Nanhu Singh, whom he initiated ${ }^{13}$ into the sect in 1933 under the name of Digvijaynath. According to Briggs (1973), "Nanhoo Singh who was involved in the suit and who hoped to win the gaddi, was not a Yogi at all. He stated that if he had won his case at law, he had intended to undergo initiation, become a Yogi, and have his ear split" (p. 37). In fact, it is his guru who won the case, but Brahmanath died only two years later and in 1935, Digvijaynath acceded to the throne of mahant. After these years of conflicts and mismanagement, the monastery needed repair and good governance, and entrepreneurial skill was very much welcomed. Also among the Yogis, Digvijaynath's reputation of having been protected and educated by such a great Yogi as Gambhirnath gave him credibility, and his accession as the successor of his guru to the gaddi gave him institutional legitimacy. ${ }^{14}$ As soon as he acceded he started to expand his influence inside the sect by joining the Yogi Mahasabha, the Yogi association founded in 1906, and succeeded in making the Gorakhpur mahant "'hereditary' president of this body." ${ }^{15}$ 

entrepreneurial and political activities. He rebuilt the monastery and the temple, began several educational foundations and among them, the Maharana Pratap Siksha Parishad Trust, from the name of the illustrious Maharaja of Mewar Pratap Singh, famous for his struggles against the Moghols. Digvijaynath claimed to belong to this Sisodya dynasty: "In his body runs the blood of the Sisaudiya, that is why he is full of love for the people and the dharma Hindu (Hindu jati aur dharma)" (Mahant Digvijaynath smrti-granth 1971:169) ${ }^{16}$ This love for "Hindu dharma" would be the guideline of his political involvement which clung close to Savarkar's ideas and led him to join the Hindu Mahasabha in 1937. He was involved in many of the Mahasabha's initiatives such as cow-protection movements and movements for the liberation of the birthplace of the God Ram and he was elected to the Loksabha in 1967, an initial move which his two successors would imitate. "He was the Maharana Pratap of his time for the Hindus. His person united the strength of the Brahmin and of the Ksatriya" (Mahant Digvijaynath smrti-granth 1971:176).

The new orientation initiated by Digvijaynath would dominate the following story of the math and the actions of his successors to mahantship, Avedaynath and Adityanath. What is constantly put forward is their Ksatriya or Thakur caste identity, and their involvement in the defense of Hinduism: their warrior force is for the Hindu dharma. Their belonging to a spiritual tradition devoted to a search for asceticism and liberation is put aside. And hagiographical writings about these mahants, instead of praising their "yogic power" (yogbal), praise their "conquering power" (ksetrabal), materialized through new administrative settlements and territorial electoral conquests.

Avedyanath, born to a Garhwali Ksatriya family, got involved in the Gorakhpur math quite young. Initiated by Digvjaynath in 1942 and soon nominated uttaradhikari, wouldbe successor, he followed his guru in the Hindu Mahasabha and was elected a member of the UP local assembly five times, and four times at the Loksabha (Parliament lower house), in Gorakhpur circumscription. His involvement in the Hindutva agenda secured him presidentship of the Ayodhya based movement for the liberation of Ram's birthplace in 1984. Situated in UP, Ayodhya and the conflict around the Babri Masjid and the Ram Temple were a permanent focus in the political involvement of the Gorakhpur Mahants until quite recently when Adityanath was seen and publicized leading a procession carrying the Ram statue to the future abode of the temple the very day when Narendra Modi was establishing the covid-19 lockdown. ${ }^{17}$

17 Adityanath is the disciple and successor of Avedyanath, besides being his nephew (on maternal side). Born in 1972, also to a Garhwali Ksatriya family, he got a very early start in politics, competing in a students' union election as an independent candidate, ${ }^{18}$ and later was elected in the 1998 national election on a BJP ticket, being the youngest member in the Loksabha. Reelected over and over again, he was appointed as the BJP Chief Minister of Uttar Pradesh in 2017, by the Prime Minister Narendra Modi.

\section{Adityanath's power characteristics}

One may summarize his behavior and his actions with three topics: Ksatriya dominance, the Hindu dimension, the hate for Muslims. The three dimensions are

South Asia Multidisciplinary Academic Journal, 24/25 | 2020 
interrelated and fill out Adityanath's performances and his strategy of omnipresence (especially in the media).

\section{The Ksatriya side}

19 The town of Gorakhpur has been well known for its mafia-style mix of business and politics. According to Chaturvedi, Gellner and Pandey (2019), violent confrontation started with a rivalry around the creation of an university:

What is universally agreed in all accounts of Gorakhpur politics of the late 1950s and 1960s is that the university committee became a battleground between the two dominant personalities, S.N.M. Tripathi and Yogi Digvijayanath, and therefore between Brahmins and Thakurs. Each side began to recruit 'muscle power' in order to bolster their case. Furthermore, one of the few things on which there is also agreement is that this led to the rise of caste-inflected gangsterism in eastern UP as a whole. (P. 47).

This gangsterism, as they demonstrate, expanded in the following decades, with hard competition among politicians cum businessmen and various attempts by state governments to curb or enlist the main protagonists: "In the 1970s, 80s, and 90s, gangster rivalries and gory murders became the everyday narrative of local politics" (Chaturvedi et al 2019:49).

However, "it is widely believed that as long as Avaidyanath was at the helm of the Goraksanath Math, there was no interference from the Math side in the local mafiapolitics nexus" (Chaturvedi et al 2019:51). ${ }^{19}$ In 1998, Avaidyanath retired from active politics for his disciple and successor Adityanath. Recently elected to the Loksabha, very young and ambitious, Adityanath needed to assert his authority and, true to Gorakhpur's reputation as a place devoted to muscle power, he started by recruiting groups of young people, often unemployed but educated and from upper-caste backgrounds, as a sort of private army or militia, the Hindu Yuva Vahini, ${ }^{20}$ founded in April 2002 in the aftermath of the Gujarat riots (and to avenge the burning of the Sabarmati Express at Godhra). Its headquarters were inside the Gorakhpur math compound, but the HYV expanded all over eastern UP. According to Intelligence reports quoted in the independent online media The Print,

Since public has faith in Gorakh Peeth, HYV members are spread till village level in various districts. The appeal among youths towards this organization continues to grow because after joining the organization, its members are safeguarded from police/administrative action, and they receive favors in administrative offices due to their association with the organization. (Bhardwaj January 17, 2020)

This fact was rather accepted since at first it was perceived as a useful tool against previous gangster violence:

This "youth force" has provided Adityanath with the "muscle power" that he needed to establish himself as the pre-eminent leader in the region, and also to counteract the power of the mafia dons. Adityanath explicitly took credit for wiping out gangsterism in Gorakhpur in his speech to the Vidhan Sabha following the BJP's election success in 2017. Many local businessmen are clear that they much prefer the hegemony of the Math to that of the gangsters. (Chaturvedi et al 2019:52) 
However, as we shall see later, this was achieved to the detriment of the Muslims.

Adityanath's Ksatriya style and manner of occupying the math was very clear even before he became Chief Minister. He was well informed of all the math's institutions and personally looked over their activities. He went often on inspection tours, always accompanied by armed bodyguards, but back in his office in the monastery he was very accessible. Every day, at his desk in a long hall, he heard people's demands, most often for educational or medical help. Busy with the phone to resolve problems or to summon people, he had the attitude of a powerful landlord or politician, holding what was called "a janta darbar," a people's court. Administrative and political questions were more often on the agenda than religion as such.

\section{The Hindu/Hindutva side}

Before being a local leader Adityanath, is first and foremost the head of a monastery, a religious figure who belongs to an ascetic community. He likes to put forward his ascetic lifestyle ${ }^{21}$ how he wakes up at dawn ${ }^{22}$ is dedicated to work, ${ }^{23}$ and devoted to cows with a visit to a cowshed as the first part of his daily routine. His dress is the very simple ochre robe of his order and his bare head emphasizes his ascetic shaving. He is said to practice yogic exercises, but I cannot say whether he is following a spiritual path.

Inside the sampradaya he is recognized as an important authority. The last three mahants of Gorakhpur math have tried and succeeded to be recognized as leaders for the Nath sect and to transform the Gorakhpur math, which was one among many niji, i.e. private, monasteries, into a hub for the whole sect. As we have seen, Digvijaynath has secured for himself and for the Gorakhpur mahants who have come after him the position of president of the Yogi Mahasabha, the modern-day association which unifies, controls and promotes the Nath sect. The Mahasabha leaders' presence is requested for all the main events related to the sampradaya. Of course, the death and inhumation of Avedyanath in 2014 was the occasion for a large gathering both of Nath sadhus and politicians (among whom L.K. Advani and Rajnit Singh, then Union Home Minister) who honored the consecration of Adityanath as his successor on the throne of Gorakhpur the next day. Since 1998, Adityanath had already been in charge of the affairs of the monastery (as uttar-adhikari, future successor) as Avedyanath had decided. But the public funerals of his guru and predecessor and his enthronement the next day by the sectarian authorities, in front of a huge crowd of Yogis, Gorakhpur citizens and highlevel politicians, gave him both public recognition and sectarian legitimacy. Thus, for the funerals of the last mahant of the huge Asthal Bohar monastery, Cand Nath who was also a BJP MLA, and for the enthronement of his successor, Adityanath was present as the highest Nath authority and the main guest (alongside Ramdev). He took advantage of the large press coverage to give vehement speeches. They were not so much about the sampradaya and its long tradition, which the new successor would now have to endorse, but rather about Hinduism in general. This is the new turn which started with Digvijayanath and the building of the new Gorakhpur temple: the enrolment of Gorakhnath and the Nath Yogis under the banner of global Hinduism as represented by sanatan dharma. ${ }^{24}$ If the Gorakhpur religious compound includes at its center, as it is the norm in Nath establishments, a Gorakhnath temple with statues of the main Nath Siddhas, a holy fire-place (dhuni), and the tombs of the previous mahants, it also 
includes a great number of smaller shrines devoted to other Hindu deities, in addition to a large temple to Hanuman, and galleries of statues and paintings celebrating the main divine and human figures who made the glory of India (Gandhi excepted). ${ }^{25}$ The printed production of the math also echoes a vision of Hinduism, philosophically more neo-vedantic than yogic, which overshadows the specific Nath heritage. Moreover, the new world success of Yoga, which Narendra Modi was then eager to promote as a Hindu heritage, is an element which tends to strengthen the inclusion of Nath Yogis into mainstream Hinduism. And Yoga is included in the strong Hindu nationalist verbal strategy of Adityanath: in 2015, he declared on International Yoga Day: "Those who do not want to practice yoga or the suryanamaskar should drown themselves into the sea" (Singh 2018:58). ${ }^{26}$

\section{Hate for Muslims}

Since the beginning of his public career, Adityanath's commitment to Hinduism was inseparable from his hate for Muslims. In strict Hindutva logic, he stigmatized Muslims as anti-national. Adityanath is not interested in Islam itself-its religious philosophyand is apparently ignorant of the past exchanges between Naths and Sufis. He also refuses the former situation in Gorakhpur where the Muslims identified with the math, and where the Miya Sahib and the Gorakhpur mahant had friendly relationships. The 2007 riots for which Adityanath and his Hindu Yuva Vahini were considered responsible even started during a muharram procession. It just so happened that the procession crossed the path of a Hindu marriage cortege. Some young people started to shout, someone from the Hindu cortege fired in the direction of the procession, people were wounded, the Muslims caught the man who had fired and beat him up. The next day he died in the hospital. Adityanath called the Hindu Yuva Vahini, made inflammatory speeches, a mosque was attacked, and the police decreed a curfew. Adityanath did not comply with it, was arrested and put in jail for one week. During this time the Hindu Yuva Vahini wreaked havoc throughout the Muslim quarters around the math, and even burned train coaches. At least ten people died. Later the following statement (published in Tehelka on February 17, 2007) is attributed to the District Magistrate Hari Om: "He [the DM] wishes to put it on record that not a single incident of slogan-shouting or stone-pelting was resorted to by Muslims. He wants the world to know that although much grieved by the decision to impose curfew as it hampered Muharram, the Muslims, led by the venerable Miyan saheb, assured the administration of all cooperation as peace was more important and kept their word." Adityanath was released from jail and triumphantly paraded through the town by his followers. However, a complaint was made against him at the Allahabad High Court and the State government, at the behest of Mulayam Singh Yadav, decided to withdraw the security detail provided to him, to the dismay of an openly weeping Adityanath. ${ }^{27}$

These communal riots were not at all an isolated event: between the foundation of the HYV in 2002, and the year 2007, there were twenty-two riots involving Adityanath and his group in Gorakhpur and the surrounding area. ${ }^{28}$

Initiatives and declarations targeting Muslims have been a constant in Adityanath's activities before and after his accession to the Chief Ministership. ${ }^{29}$ They range from changing names in Gorakhpur (Alinagar to Aryanagar, Miyan Road to Maya Road, Urdu Bazar to Hindi Bazar), to the "love jihad" campaign ("for one Hindu girl seduced by a 
Muslim, Hindu men will seduce hundred Muslims girls"30), or gruesome statements ("Muslims can go to Pakistan or kabristan," i.e. the cemetery). Most violent attacks have to do with the issue that yokes together militant Hinduism and hate for Muslims: cow protection. ${ }^{31}$ Many cases of Muslims accused of cow smuggling, of slaughtering cows or trading cow meat have ended tragically and one of Adityanath's first initiatives as Chief Minister was the approval of the "Cow Protection Committee" (gau sewa aayog), which was set up in each UP district, headed by the District Magistrate and Police Chief, backed by two private "cow-loving persons," and bolstered by the immediate banning of all illegal slaughterhouses (and most of them were not approved).

In the most recent events, Adityanath's contributions to the public debate have been along the same anti-Muslim line: when he entered the election campaign for the 2020 Delhi Legislative Assembly elections, he attacked the Chief Minister of Delhi Arvind Kejriwal, the leader of the Aam Aadmi Party, as "supporting the Shaheen Bagh protesters and feeding them with biryani" and claimed: "people who don't listen to boli [words] will listen to police goli [bullets]." ${ }^{22}$ The AAP demanded a campaign ban on him in Delhi (Economic Times, 2 February 2020). And in UP he attempted to fine the anti-CAA protesters for supposed destruction to public property. He also ordered posters to be put on Lucknow walls with the names and photos of Anti-CAA protesters. ${ }^{33}$ And during the first days of the covid-19 pandemic, he held the Tablighi Jamaat congregation members responsible for its spread: "In Uttar Pradesh and other places where the spread of the coronavirus has been seen, Tablighi Jamaat is behind it" (NDTV, 4 May 2020)..$^{34}$

28 A summary of the accusations charging the UP Chief Minister and his present antiMuslim initiatives can be found in the statement issued by the People's Tribunal on State Action in UP, held on $16^{\text {th }}$ January, 2020 at the Indian Society of International Law, in New Delhi: "The entire state machinery led from the top acted with grave prejudice and perpetrated violence targeting one particular community, the state's Muslim population." The report lists the many examples of violence from UP police and state administration and concludes: "the state of affairs in UP shows a complete collapse of rule of law" (see South Asia Citizens Web Staff. 2020a).

\section{Adityanath's assets}

\section{His activism}

Obviously, this report does not represent the opinion of all UP citizens. Other voices can be heard who rejoice that "with Adityanath things are being done." His first days in charge have been replete with declarations and decisions aiming at good governance for a "corruption-free" and "crime-free" UP, the "end of jungle-raj" which was inherited from his predecessor. He himself wrote a report of his first 100 days in office, "100 Din Vishwas," 35 listing his key decisions. Following Manoj Singh's (2018) compendium of declarations and press reports, one can make the list of Adityanath's "Top 16 decisions in 30 days" (pp. 110-13), such as asset declaration by administrative managers, cleanliness, a farm-loan waiver for poorer peasants, power supply, roads improvements, longer working hours in the administration. But some measures had dire consequences such as the anti-Romeo squads (supposed to protect the safety of women but sometimes resulting in aggressive "moral policing" brigades), meat 
crackdown (with cases of burning meat shops), police encounters with criminals, ${ }^{36}$ and measures to attract would-be investors (Singh 2018:125-29). ${ }^{37}$ Whatever one thinks of his activism, it cannot be denied. It goes along with massive press coverage. Every day various media report on his actions, declarations, inaugurations of a new project, with interviews, videos, and press conferences. This "politics of presence" (Hansen, quoted in Chaturvedi et al 2019:53), or "politics of permanent performance" (Chaturvedi et al 2019:53) was not only for UP since Yogi Adityanath has been recruited as a champion campaigner by the party in power and has been reported to tour the country during electoral campaigns.

\section{What kind of advantage does Adityanath represent for the BJP?}

30 First his caste background: himself a Thakur as we have seen, inheritor of a former gang-like rivalry situation between Thakurs and Brahmans in Gorakhpur, he generally has the support of the Kshatriyas. However, Brahmans also support him because they mostly vote BJP and because of his constant pro-Hindu affirmations. Thus, he has had the support of upper castes.

But Gorakhpur also has an important population of $\mathrm{OBC}$ and Dalits who were ideologically close to the monastery. The Nath sampradaya has never before been a center of Brahmanic orthodoxy; related to the Sants' open tradition, Naths are open to a broad recruitment base and the ascetic denial of the life characteristics previous to initiation may be said to mask their supposedly low-caste background. Whatever the case may be, the Gorakhpur math was considered as a place open to all. And logically $\mathrm{OBC}$ and Dalit voted for the monastery, hence for Adityanath. ${ }^{38}$ The trust they had in the Nath sampradaya is naturally passed on to its monastic leader, whose yogic status carries the weight of illustrious and powerful forbearers.

This large base of potential support, which transcends the caste vote bank, gives Adityanath the capacity to enlist all communities, Muslim excepted (which was not the case before Adityanath when Muslims were a vote bank for the math). Hence his cooptation by the BJP represents a highly valuable asset to compensate for the BJP reputation as a Brahmans' party, in the context of the rise of BSP and SP in UP. The Gorakhpur monastery is thus a key element in the BJP's strategy to enlarge its clientele. ${ }^{39}$ But, if Adityanath is now a leading BJP member, this has not always been the case and the relationships between the Gorakhpur mahant and the party have had their ups and downs. Adityanath has not always been supportive of the BJP candidate and has sometimes preferred his own men, knowing that his strong Hindu Yuva Vahini network gives him independence. ${ }^{40}$

\section{What can we say of his position now, three years after his nomination as CM?}

33 He seems to be working as the extreme right activist for the party, making controversial declarations, which allows Narendra Modi or even Amit Shah to appear as relatively more moderate. ${ }^{41}$ And he has been obedient to the orders to control the HYV, which can appear to be less active. As Pramod Mall, the HYV's Uttar Pradesh state general secretary, has said, justifying what has changed: "Earlier we had governments busy in appeasing minorities, subjugating Hindus, enjoying corruption. We had to 
struggle for justice," he says. "But now we have such a great government it's for all to see. The Hindu Yuva Vahini now gets its work done silently through democratic means because the government listens to us" (Vij 2019). However, the choice of Adityanath as $\mathrm{CM}$ has taken people by surprise and was not unanimous nor fast: some say that he was not the BJP's first choice but was imposed by the RSS. What is now his margin of autonomy? Is the UP model, described by Zoya Hasan as "communal authoritarianism" (Hasan 2020), an original model? Narendra Modi is not reputed to like strong or popular personalities in his close entourage, people susceptible to outshine him: is he controlling Adityanath ${ }^{42}$ ? But if he wants to stick to the image of the ascetic Prime Minister devoted to the Hindu cause, he risks being outmatched by the one who is a true ascetic, an initiated Yogi for whom saffron is the color of his Shaiva sectarian belonging and not only a banner or a painted building. ${ }^{43}$

\section{BIBLIOGRAPHY}

Banerjea, Akshaya Kumar. 1979. The Nath-Yogi Sampradaya and the Gorakhnath Temple. Gorakhpur: Mahant Digvijaynath Trust.

Bevilacqua, Daniela. Forthcoming. "Towards a Nath Re-appropriation of Hatha Yoga." in The Powers of the Nath Yogis: Yogic Charisma, Political Influence and Social Authority, edited by D. Bevilacqua and E. Stuparich. Amsterdam: Amsterdam University Press.

Bhattacharya, France. 2003. "Un Texte du Bengale médiéval: le yoga du kalandar (YogaKalandar). Yoga et soufisme, le confluent de deux fleuves." Bulletin de l'École française d'ExtrêmeOrient 90-91:69-99.

Bouillier, Véronique. 2015. “Nath Yogis' Encounters with Islam.” South Asia Multidisciplinary Academic Journal. Retrieved on October 20, 2020 (http://samaj.revues.org/3878).

Bouillier, Véronique. 2017. Monastic Wanderers: Nâth Yogî Ascetics in Modern South Asia. Delhi: Manohar.

Bouillier, Véronique. 2018. "Aurangzeb and the Nath Yogis." Pp. 525-35 in From Outside the Persianate Centre: Vernacular Views on "Alamgir," edited by A. Murphy and H. Pauwels. JRAS, Series $3,28(3)$.

Briggs, Georges Weston. 1973. Gorakhnath and the Kanphata Yogis. Delhi: Motilal Banarsidass [first ed. 1938]

Cashin, David. 1995. The Ocean of Love: Middle Bengali Sufi Literature and the Fakirs of Bengal. Stockholm: Association for Oriental Studies.

Chaturvedi, Shashank. 2016. "Religion, Culture and Power: A Study of Everyday Politics in Gorakhpur.” PhD dissertation, Center for Political Studies, JNU.

Chaturvedi, Shashank, David Gellner, and Sanjay Kumar Pandey. 2019. "Politics in Gorakhpur since the 1920s: The Making of a 'Safe' Hindu Constituency." Contemporary South Asia 27(1):40-57. 
Digby, Simon. 1970. "Encounters with Jogis in Indian Sufi Hagiography." Presented at the SOAS Conference, London.

Ernst, Carl W. 2016. Refractions of Islam in India: Situating Sufism and Yoga. New Delhi: Yoda Press/ Sage.

Gold, Daniel. 1995. "The Instability of the King: Magical Insanity and the Yogi's Power in the Politics of Jodhpur, 1803-1843." Pp. 120-32 in Bhakti Religion in North India: Community Identity and Political Action, edited by D. N. Lorenzen. Albany: SUNY Press.

Green, Nile. 2008. "Breathing in Inda, c. 1890.” Modern Asian Studies 42(2/3):283-315.

Hatley, Shaman. 2007. "Mapping the Esoteric Body in the Islamic Yoga of Bengal." History of Religions 46(4):351-68.

Jaffrelot, Christophe. 2019. L'Inde de Modi. National-populisme et démocratie ethnique. Paris: Fayard. Jha, Dhirendra K. 2017. Shadow Armies: Fringe Organizations and Foot Soldiers of Hindutva. New Delhi: Juggernaut Books.

Kasturi, Malavika. 2018. "Negotiating the Sacred in Twentieth Century Gorakhpur: The Nathyogis, the Gorakhnath Math and Contested Urban Space." Pp. 215-40 in Urban Spaces in Modern India, edited by N. Gupta and P. Datta. Shimla: IIAS.

Mahant Digvijaynath smrti-granth, 2026 VS. 1971. Gorakhpur.

Pinch, William R. 2006. Warrior Ascetics and Indian Empires. Cambridge: Cambridge University Press.

Singh, Manoj. 2018. Yogi Adityanath. Delhi: Akshay Books.

Speziale, Fabrizio. Forthcoming. "Beyond the 'Wonders of India' ('ajā'ib al-Hind): Yogis in Persian Medico-alchemical Writings in South Asia."

\section{PRESS REFERENCES}

Ali, Subhasini, 2020. "Far from Helping Workers, the Adityanath Govt is Bent on Snatching Away Their Rights." The Wire, May 17. Retrieved on October 20, 2020. (https://qoshe.com/the-wire/ subhashini-ali/far-from-helping-workers-the-adityanath-govt-is-b/73400139).

Bhatia, Sidharth. 2020."Forget Gujarat, the Future Belongs to the Uttar Pradesh Model." The Wire, 0ctober 1. Retrieved on October 20, 2020 (https://thewire.in/politics/uttar-pradesh-modelsangh-parivar-yogi-adityanath).

Economic Times Staff. 2020. "AAP demands campaign ban on Adityanath in Delhi," Economic Times, February 2. Retrieved on October 20, 2020 (https://economictimes.indiatimes.com/news/ politics-and-nation/aap-demands-campaign-ban-on-adityanath-in-delhi/articleshow/ 73878531.cms).

Economic Times Staff. 2020. “Yogi Adityanath's Father Dies; UP CM Says Can't Attend Funeral." Economic Times, April 20. Retrieved on October 20, 2020 (https://economictimes.indiatimes.com/ news/politics-and-nation/up-chief-minister-yogi-adityanaths-father-passes-away/articleshow/ 75247233.cms).

Gatade, Subash. 2004. "Hindutvaisation of a Gorakhnath mutt: The Yogi and the Fanatic." South Asia Citizens Web, October 7. Retrieved September 9, 2020 (http://www.sacw.net/DC/ CommunalismCollection/ArticlesArchive/gatade07102004.html).

Gautam, Chikermane and Rishi Agrawal. 2020. "Covid-19: Yogi Adityanath Attempts Reforms, Delivers Regulatory Chaos in Uttar Pradesh.” Orfonline, May 9. Retrieved on October 20, 2020 
(https://www.orfonline.org/expert-speak/covid19-yogi-adityanath-attempts-reforms-deliversregulatory-chaos-uttar-pradesh-65918/).

Ghosh, Paramita. 2010. “The Hungry Artistes.” Hindustan Times, April 4. Retrieved on October 20, 2020 (https://www.hindustantimes.com/india/the-hungry-artistes/story-

ghismBe0IaXnsWxwjhzyLK.html).

Hasan, Zoya, 2020. “Move Aside 'Gujarat Model', the UP Model Has Arrived." The Wire, 29 May. Retrieved on October 20, 2020 (https://thewire.in/politics/bjp-uttar-pradesh-model-adityanath).

Marrewa-Karwoski, Christine. 2018. “The Erased 'Muslim' Texts of the Nath Sampradaya." The Wire, March 23. Retrieved on October 20, 2020 (https://thewire.in/religion/the-erased-muslimtexts-of-the-nath-sampraday).

Mehta,Pratap Bhanu, 2020. “Thoki Raj: Creating Order by Trampling on Law is One of the Elements of Adityanath's Ideological Success.” The Indian Express, July 11. Retrieved on October 20,2020 (https://indianexpress.com/article/opinion/columns/vikas-dubey-encounter-case-uppolice-6499823/).

Newsclick Report. 2018. “This is How Much the Yogi Government Loves Cows.” Newsclick. February 22. Retrieved on October 20,2020 (https://www.newsclick.in/how-much-yogi-government-lovescows).

NDTV Staff. 2020. "Yogi Adityanath Blames Islamic Sect for Spread of Coronavirus." NDTV, May 4. Retrieved on October 20,2020 (https://www.ndtv.com/india-news/yogi-adityanath-blamesislamic-sect-tablighi-jamaat-for-spread-of-coronavirus-2222426)

Peoples Democracy, 2017. “This is Yogi Adityanath.” Newsclick, March 25. Retrieved on October 20, 2020 (www.newsclick.in/yogi-adityanath).

The Print Staff. 2020. "Lucknow Names and Shames Anti-CAA Protesters on Hoardings for 'Damaging Public Property."' The Print, 7 March. Retrieved on October 20, 2020 (https:// theprint.in/india/lucknow-names-shames-anti-caa-protesters-on-hoardings-for-damagingpublic-property/377088/).

Rajput, Abhinav, 2020. “On Day 1 in Delhi, Yogi Talks Bullets, Biryani and Protests." The Indian Express, February 2. Retrieved on October 20, 2020 (https://indianexpress.com/elections/delhielection-yogi-adityanath-talks-bullets-biryani-shaheen-bagh-protest-6246698/).

Rashid, Omar. 2020. "Uttar Pradesh Police Lodged FIR against the Editor of The Wire for 'Objectionable' Article against Yogi Adityanath.” The Hindu, April 2. Retrieved on October 20, 2020 (https://www.thehindu.com/news/national/other-states/uttar-pradesh-police-lodge-firagainst-the-editor-of-the-wire-siddharth-varadarajan/article31231478.ece).

Shahu, Manish and Apurva Vishwanath. 2020. "Encounters Impunity on Record: 74 Probes Complete in UP, Police get Clean Chit in All." The Indian Express, July 11. Retrieved on October 20, 2020 (https://indianexpress.com/article/india/74-probes-complete-in-up-police-get-clean-chitin-all-6500071/).

Shankar Aranya, Aranya Tiwari and Manoj CG. 2020. "Hathras Echoes in Delhi, Oppn Leaders Slam ‘Cover up' by Yogi Gvt; Some Seek Removal.” The Indian Express, October 3. Retrieve on October 20, 2020 (https://indianexpress.com/article/india/hathras-echoes-in-delhi-oppnleaders-slam-cover-up-by-yogi-govt-some-seek-removal-6672509/).

Singh, Kautilya. 2017. "Dad to Adityanath: Women in Burqa Too Voted for You." Times of India, March 22. Retrieved on October 20, 2020 (https://timesofindia.indiatimes.com/city/dehradun/ dad-to-aditya-nath-women-in-burqa-too-voted-for-you/articleshow/57763049.cms). 
South Asia Citizens Web Staff. 2020a. "India: Statement from the Jury- People's Tribunal on State Action in UP, Held on the $16^{\text {th }}$ January 2020 in New Delhi." SACW, January 19. Retrieved on October 20, 2020 (http://www.sacw.net/article14257.html).

South Asia Citizens Web Staff. 2020b. "India: Open Letter to The Chief Minister of Uttar Pradesh Blatant Violations of The Rule of Law | Former State Officials." SACW, October 8. Retrieved on October 20, 2020 (http://www.sacw.net/article14459.html).

Times Now Staff. 2018. "Haj House in Lucknow Painted Saffron by the Yogi Adityanath Government.” Times Now, January 05. Retrieved on October 20, 2020 (https:// www.timesnownews.com/india/article/haj-house-lucknow-yogi-adityanath-mohsin-raza-uttarpradesh-chief-minister-saffron/185487).

Verma, Lalmani, 2017. "Uttar Pradesh Govt. Paints the Town Saffron: Buses to School Bags, Booklets to Furniture.” The Indian Express, October 12. Retrieved on October 20, 2020 (https:// indianexpress.com/article/india/yogi-adityanath-govt-bjp-uttar-pradesh-saffron-buses-schoolbags-booklets-furniture-4886093/).

Vij, Shivam, 2019. "With Yogi as CM, His Hindu Yuva Vahini has all but Disappeared from Gorakhpur," The Print, May 14. Retrieved on October 20, 2020 (https://theprint.in/politics/withyogi-as-cm-his-hindu-yuva-vahini-has-all-but-disappeared-from-gorakhpur/235208/).

Zee Media Bureau. 2017.“When Yogi Adityanath Cried Bitterly in Parliament.” Zee News, Updated March 20. Retrieved on October 20, 2020 (https://zeenews.india.com/india/when-yogiadityanath-cried-bitterly-in-parliament-because-of-mulayam-singh-yadav-watch-viralvideo_1988404.html).

\section{NOTES}

1. With many thanks to Jules Naudet and Aminah Mohammad, and the two anonymous reviewers for their thoughtful and helpful comments. Many thanks also to Francie Crebs for her precious help in improving the ms.

2. The Yogis went one step further in this direction when they so completely subjugated the Jodhpur Raja Man Singh that they ended up taking full control of the kingdom's administrationwithout ever replacing the Raja (see Gold 1995).

3. This was already the topic of a 2015 article I published in SAMAJ, "Nath Yogis' Encounters with Islam," to which I refer.

4. See Cashin (1995); Ernst (2016); Bhattacharya (2003-2004); Green (2007); Hatley (2007)

5. See Bouillier (2018:528): “as Nevill remarks in his Gazetteer of Gonda, any

aggressive attempt from Aurangzeb on Devi Patan is improbable, since 'from the days of Akbar to the epoch of the Nawab Wazirs of Oudh...the [Gonda] tract is practically beyond the sphere of imperial power...Gonda never figures in the Musulman Annals."”

6. In Urdu, a Shia congregation hall; also, as in this case, a large tomb.

7. This story, locally well-known, is reported by S. Chaturvedi (2016:188). I found no mention of it in the written sources, nor the books and booklets published by the monastery nor its website. The websites of the imambara (and the blog of Mazhar Naqvi) give more detail on the charismatic figure of Roshan Ali Shah and his encounter with the Nawab. The Nawab gave the imambara the revenues of 17 villages in the surrounding areas, and many golden tazias (miniature mausoleums carried during muharram processions).

8. Numerous legal conflicts have cropped up recently due to the Adityanath's contesting proprietary or tenure acts in order to reoccupy this Muslim land. On the long history of 
negotiations and conflicts between the math and its Julaha tenants, which started with what she calls the politics of kabza (encroachments) of Digvijaynath, see Kasturi (2018).

9. See a declaration issued by Adityanath's father saying that even women in burqa had voted for the math and have to be respected (Singh 2017) The area had at least 50,000 weavers and they used to vote for the math's candidate, at least until the 70s (see Chaturvedi 2016:188).

10. See Singh (2018) and Ghosh (2010).

11. First founded as the organization Sarvadeshak Hindu Sabha (Hindu Assembly for the Entire Country) to protect the rights of Hindus, it changed in 1921 to the present name Akhil Bharatiya Hindu Mahasabha (All-India Hindu Grand Assembly), and became a political party devoted to the promotion of Hindu nationalism, whose ideology is similar to the RSS program.

12. According to a book published in Digvijaynath's honor in 1971, Mahant Digvijaynath smrtigranth, which includes biographical elements, extracts of his writings, and various testimonies and praises of his entourage. The greater part of the book is devoted to his political position and initiatives. The part entitled vivâd (conflicts), Pp. 165-66, provides details on these succession issues. See also the article by Malavika Kasturi (2018), who had access to many legal documents from the Gorakhpur civil court.

13. On the successive steps leading to full initiation, i.e. the splitting of the ear cartilage and the granting of a mantra which ultimately leads to liberation, see Bouillier (2017:41-45).

14. Gorakhpur monastery is a personal property (a niji math), and the succession passes from guru to head disciple. Usually the dying mahant nominates his would-be successor, if not the situation leads to contests between the various disciples. The death of the mahant is followed by his burial within the precincts of the math and the immediate ritual of consecration of the new incumbent, who is symbolically accepted by all attendant Yogis, other mahants and sectarian authorities, who wrap him with a shawl (for Gorakhpur, see a description in Briggs [1973:36-37], and for the Nath Yogis-particularly in Kadri monastery-Bouillier [2017:124-63]).

15. Malavika Kasturi (2018:224), who considers Digvijaynath to be responsible for the renaming of the association Akhil Bharatvarsiya Avadhut Bhes Barah Panth Yogi Mahasabha as early as 1924. On the status and function of the Mahasabha see Bouillier (2017:57-68).

16. Quoted from Rameshwar Simha.

17. The Wire, which reported the fact, was slapped with a lawsuit on Adityanath's order and its Editor-in-Chief charged (about a declaration regarding the polemic: "Lord Ram would protect devotees from the coronavirus," wrongly attributed to Adityanath who nevertheless led the Ayodhya procession, see Rashid (2020).

18. He did not get the ABVP ticket, and lost the election (see Singh 2018:19)

19. It is hard to believe since for instance, the 1996 elections were contested between Mahant Avaidyanath and ex-"roadside hooligan" and MLA, V.P. Shahi, as Chaturvedi et al. (2019:49) also note.

20. On its website, the Hindu Yuva Vahini (HYV) describes itself as "A fierce cultural and social organization dedicated to Hindutva and nationalism." Its stated objectives are: "the integration of and mutual good faith within the massive Hindu society, through the complete abolishment of the differentiation between touchable-untouchable and high-low, promote the harmonious development of society." On HYV's organization, activities and personal links to Adityanath, see Dhirendra Jha (2017:33-58).

21. During his official visits, he refused all the trappings of Chief Minister: red carpet, AC or air cooler, sofa etc. (Singh 2018:123)

22. "He wakes up at 3 in the morning...the auspicious time that is ideal for yoga, meditation and all sort of religious practices...[Then] he starts his day with gau seva...feeding the cow (sic) with the green fodder" (Singh 2018:20)

23. For instance see press reports about the death of his father and the way he continued to attend to his duties: "The funeral which will not be attended by the CM, who said he is duty- 
bound to stay in his state" (Economic Times, April 20, 2020). This is a little ironic considering that an ascetic is supposed to have cut all ties with his natal family, not to visit them nor to attend funerals. However, as far as I know, this is seldom the case and Adityanath is no exception in keeping strong links with his family.

24. The "eternal dharma," a term used by reformists to refer to Hinduism as a unified world religion, irrespective of any sectarian divide. It inspires what is known since the $19^{\text {th }}$ century as neo-Vedanta, neo-Hinduism or global Hinduism. From the emergence of nationalist movements, this Hinduism was conceived as coextensive to the Indian nation and nourishes the Hindutva ideology of Hinduism as an encompassing world religion.

25. Digvijaynath was accused of being involved in Gandhi's assassination, and even went to jail for nine months (Chaturvedi et al. 2019:44).

26. Suryanamaskar is iconic of the postural neo-Yoga which developed very differently from the Nath tradition. On the promotion of this world Yoga even in the Gorakhpur monastery, see Daniela Bevilacqua (forthcoming).

27. The videos of the incident (March 12, 2007) went viral on You Tube (see for instance Zee News 20 March 2017). See its analysis in Dhirendra Jha (2017:50-51).

28. See. Peoples Democracy March 25, 2017.

29. Other Nath Yogis were not always in agreement with his inflammatory declarations and practices and I know of Nath sites where he was not welcome and not allowed to give speeches, even though his position in the sect made him officially a guest of honor. Generally speaking, Naths are divided regarding Adityanath's status and actions: some are proud of him and some very critical.

30. "Love jihad" is a way to designate the alleged attempt by Muslim men to seduce Hindu girls in order to convert them to Islam. Such an allegation appeared in 2009 in Kerala and Karnataka cases and later on Adityanath reacted to the developing controversy by such reverse slogans and the condemnation of inter-faith marriages.

31. See "This is How Much the Yogi Government Loves Cows" (Newsclick February 22, 2018)

32. See. Rajput (2020).

33. See The Print ("Lucknow Names and Shames Anti-CAA Protesters on Hoardings for 'Damaging Public Property." The Print, March 7, 2020) but this was forbidden by the Allahabad High Court.

34. And in UP, Aditynatah's government amended the law with the consequence that 300 Muslims are in jail "for spreading corona" (Ali 2020).

35. See Singh (2018: Chap. 6). Adityanath as CM would be personally taking care of some 36 ministries himself (Singh 2018:1).

36. The extrajudicial killing of the top gangster Vikas Dubey is the last one of a long series "as per records, Dubey is the $119^{\text {th }}$ accused to have been killed in what police called cross-firing since the Yogi Adityanath government took charge in March 2017" (Shahu and Vishwanath 2020). See also "Thoki Raj: Creating order by trampling on law is one of the elements of Adityanath's ideological success," Mehta (2020).

37. In the same pro-business line, on the May 8, 2020, following Covid-19 end of lockdown, UP government has been the first to edict a temporary ordinance, "Temporary Exemptions from Certain Labour Laws" which stipulates that all laws, rules and regulations covering factories, shops and offices, stand suspended for three years. It means suspension of minimum wages, extension of workable time (from 48 to 72 hours a week), suspension of 18 major laws (see a critical summary of these measures and their probable failure to attend their aim, in Chikermane and Agrawal (2020) and also the article by Subhasini Ali (2020), "Far from Helping Workers, the Adityanath Govt is Bent on Snatching Away Their Rights"). However, the extension of workable time has been immediately suspended by Allahabad High Court.

38. See Dhirendra Jha (2017:47-48): “This [the reputation of being a Thakur math] does not, however, stop the backward castes and Dalits of the region from supporting Adityanath. In Manoj 
Kumar's [Gorakhpur-based senior journalist] opinion, 'The support of these castes is for the math and not for any individual Mahant. Dalits and backward classes have always been attached to the math despite the latter growing antagonistic and distant from the original concept it was founded upon." However this support risks to be impeded by the attitudes of the UP authorities in the case of the Dalit girl allegedly gangraped in Hathras by Thakurs (See Shankar, Tiwari and Manoj 2020; see also the letter signed by 92 former state officials condemning "blatant violations of the rule of law in UP" and addressed to the CM, (South Asia Citizens Web Staff 2020b).

39. However, in the aftermath of the covid-19 crisis and what is felt as an abandonment of the poor by BJP government, plus the ordinance of May 8, 2020 (see note 38) and the treatment of the Hathras rape (see note 38), support from the Dalits is now far from secure.

40. See Gatade (2004) who remarks that "the nominee of the mahant won with handsome margin" [P. 4]) against the BJP nominees, at the 2004 elections to the parliament.

41. On the stigmatization of Muslims as the current rhetoric of Modi's BJP, see Jaffrelot (2019:197-214 and 251-76).

42. See the premonitory article by Gatade (2004), who in 2004, compares Modi and Yogi Adityanath, Gujarat and Gorakhpur, and states: "If there is Modi there, here is an upcoming hero 'Yogi"' (P. 5). In 2020, Sidharth Bhatia goes farther: "Forget Gujarat, the Future Belongs to the Uttar Pradesh Model;" he adds "Narendra Modi is too soft from the Sangh point of view, too concerned about his image. Not so Adityanath. And that is why Adityanath is the man of the future."

43. "Uttar Pradesh govt. paints the town saffron: buses to school bags, booklets to furniture" (Verma 2017). The government buildings, from chief minister's office to police station, and even the Haj House have been painted saffron (TimesNowNews 2018).

\section{ABSTRACTS}

This article focuses on the person of the present Chief Minister of Uttar Pradesh, Adityanath Yogi, and tries to contrast his political actions with his background as member of the Shaiva sect of the Nath Yogis. After tracing the recent history of the Gorakhpur monastery which he leads, I focus on Adityanath's mode of power, which I describe under three topics: Ksatriya power, Hindu dimension, hate for Muslims. Mentioning his last and often controversial actions and declarations, I question his relationships with the BJP and his place in the current political landscape.

\section{INDEX}

Keywords: Hindutva, Nath Yogi, Gorakhpur, Adityanath, Uttar Pradesh, Muslim.

\section{AUTHOR}

\section{VÉRONIQUE BOUILLIER}

French National Center for Scientific Research (CNRS) 